\title{
POLICY DRIVEN APPLICATION OF REMOTE SENSING IN MITIGATING URBAN SPRAWL: A CASE STUDY OF DEVELOPING NATION.
}

\author{
Pooja B. Shah ${ }^{* 1}$, Chetan R. Patel ${ }^{1}$ \\ ${ }^{1}$ Urban Planning Section, Department of Civil Engineering, SVNIT, Surat, India \\ poojabshah2512@gmail.com, chetanrpatel@rediffmail.com
}

\section{Commission III/VII}

KEY WORDS: LULC, Urban Planning, Urban Sprawl, Geospatial Techniques, Regional planning authority.

\begin{abstract}
:
Sustainable Development have drawn much attentions to the direct or indirect relationships of land use/land cover changes in past recent years. Being a limited resource, Land is critical issue to manage by the city administration in absence of effective tool. Geospatial Techniques can solve this issues of sprawl modelling and can act as decision supportive tool. This study focuses on Surat and Lucknow Indian Cities, its surrounding area to delineate a metropolitan area with the use of geospatial technology. It encompasses the jurisdictions of various urban development authorities to provide a regional context of development for the year 2035. These cities have unique characteristic of development which is investigated using remote sensing technology. Temporal analysis of study area images has deployed that there is a pressing need to control the Development because of its incessant characteristic. Role of Remote sensing is found to be very vital to understand and measure the sprawl's magnitude. Analysing the spatial dynamics of cities has escalated the need of policy making for controlled development. Insights of this study can be useful for framing policy at a regional or global level.
\end{abstract}

\section{INTRODUCTION}

Human demand for rapid urbanization and urban spatial layout has exerted pressure on land resources (Liu, 2014) (Wang, 2018). Land is an essential but limited natural resource and urbanization is one of the major land uses (Liu., 2018) In developing nation like India, this rapid urbanization fetches remarkable economic achievement in terms of the growth of the gross domestic product (GDP), the scale of industrial park construction, the scale of trade, and productivity (Bakiratas, 2018) Incessant urban development has increased the size of India's urban population. Managing urban growth has been a very complex phenomenon (Cohen, 2004) Urban expansion is often at the expense of farmland, forest, or grass (Tsutsumida, 2015), which provides essential ecosystem service to the society.

During the last fifty years the population of India has grown two-and-a-half times, but urban India has grown nearly five times. In 2001, 306.9 million Indians $(30.5 \%)$ were living in nearly 3700 towns and cities spread across the country, compared to 62.4 million $(17.3 \%)$ who lived in urban areas in 1951. This is an increase of about $390 \%$ in the last five decades (Raghavswamy V, 1996). This rapid population pressure has resulted in unplanned growth in the urban areas to accommodate these migrant people which in turn leads to urban sprawl (Atiqur Rahman, 2011) Urban growth management strategies (GMS) consist of the various tools used to manage the amount, type, extent, rate, and quality of urban development. In other words, these tools can be used to manage how much growth occurs, what kind it is, where it occurs, how fast it happens, and with what impacts. GMS can be employed at a variety of geographic scales, and by a variety of actors, usually governments (Pollock, 2008).

The role of government planners in India has changed in recent years. Planners are now seen as mediators in cooperative management process. E-government initiatives have modernised government administration. To accomplish this objective, good planning and governance are essential. The crucial prerequisite for those however, is reliable information on the condition and development of the environment. Different information technologies for collecting and analysing environmental information are in use to support planning and governance.

Remote-sensing technologies can contribute by providing upto-date and area-wide data on different aspects of the environment. There are broad collections of the literature that links LULC change detection with population dynamics (Soomro et al., 2020). According to Rawat and Kumar (2015), the variation of LULCs of a particular region reveals the natural and socioeconomic characteristics of that territory in terms of time and space. For sustainable management of natural resources, it is critical to understand the extent, management, and causes of LULC dynamics. The spatialtemporal features of the LULC provide an essential dataset for improved decision-making. The physical expressions and patterns of sprawl on landscapes can be detected, mapped, and analysed using remote sensing and geographical information system (GIS) technologies in conjunction with the secondary and ground truth data (K. B. Barnes, 2001) Until recently, the actual application of these new remote-sensing data and methods to planning and governance has been hindered by complex technological, organizational, financial, legal, and social factors. Today, different initiatives, as well as developments in web-based technologies, provide the basis for a new generation of environmental information systems to assess, communicate, and exchange environmental data. Recent developments in public administration and planning have the potential to improve integration of remote-sensing data in urban and environmental information systems used for planning and governance. The main tasks of remote sensing are to obtain environmental information, and to support the expert knowledge of specialists in a coherent and transparent way. (M. Netzband, 2007) 


\subsection{Study Area}

Present study is carried out in two cities as shown in Figure 1, which are diverse in nature in terms of sprawl, city growth and administration boundary. Surat and Lucknow are the two cities considered for the study.

City of Surat is located near coastal region and it has witnessed a tremendous amount of development in last two decades. Surat district is situated in the southern part of the Gujarat state. It lies between the parallels of latitude $20.81^{\circ} \mathrm{N}$ to 21.58 ${ }^{\circ} \mathrm{N}$ and the meridians of longitude $72.61^{\circ} \mathrm{E}$ to $73.71{ }^{\circ} \mathrm{E}$. The length from north to south of this territory is about $84.9 \mathrm{~km}$ and from east to west is about $177.7 \mathrm{~km}$. The district includes 8 statutory towns 14 census towns and 713 villages. The area covered by Surat district is 4,549 sq. $\mathrm{km}$ and having 15 th ranks in comparison to other districts of the state. It covers $2.31 \%$ of total geographical area of Gujarat, but the density of the district is 1,337 persons per sq. $\mathrm{km}$ compare to 308 the density of the Gujarat state. Surat is a historical port city and it is the fourth fastest developing city of the world. It is being an industrial hub of the country with flourishing business of diamond, textile and petrochemicals and has encroached upon the agricultural lands of neighbouring talukas. The city is not only employing locals or people from Gujarat but migrants from all over India. This resulted in heavy urbanization. Due to industries and urbanization affluent is also very high.

On the other hand, Lucknow is the capital of India's most populous state, Uttar Pradesh and is situated about $500 \mathrm{~km}$ southeast of New Delhi in the heart of the state. It is the largest and most developed city of North India after Delhi. Lucknow has always been known for its multi-cultural heritage and popularly known as Seat of Nawabs. It is also referred as the "Golden City of the East" being the trading hub for nearby towns. Lucknow is situated 123 metres above mean sea level and is located on $26^{\circ} 30^{\prime}$ and $27^{\circ} 10^{\prime}$ North latitude and $80^{\circ}$ $30^{\prime}$ and $81^{\circ} 13^{\prime}$ East longitude and generally slopes to the east. The city is spread on both the banks of River Gomti over an area of $350 \mathrm{Sq}$. Km. with a population of over 2.8 million

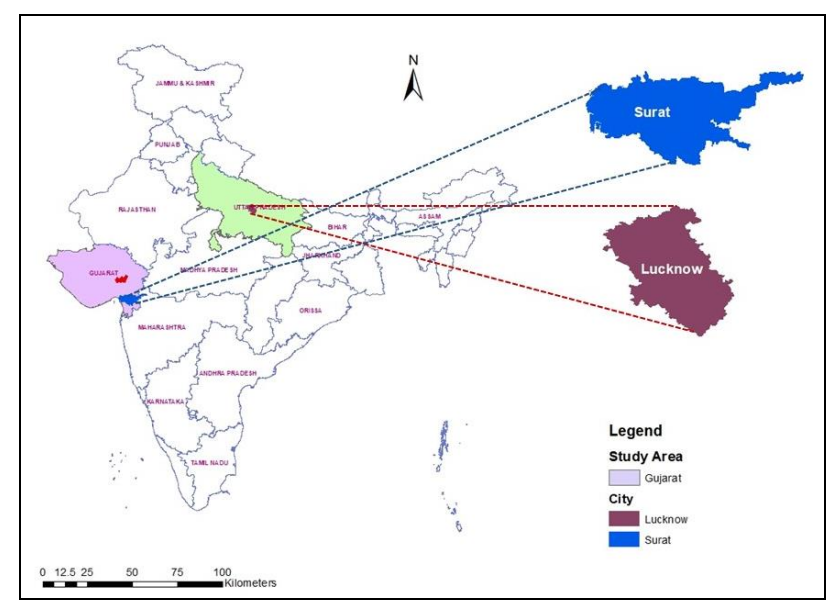

Figure 1: Study Area

\section{METHODOLGY}

\subsection{General}

Spatial and temporal growth characteristics of Surat and Lucknow are studied to understand the growth characteristic with the view of policy framing. Hypothesis of this study is to prove the need of SUPRA Region Authority, which will have power over Urban Development Authority and Municipal Corporations. Incessant anthropogenic activity leads to a need to control it for planned growth of city. Remote Sensing can be used as coherence technology by city planners, as spatial assessment of growth can be monitored and anticipated. LULC change detection is essential for studying temporal conditions and proposing better future planning and development options. (Soomro et al., 2020) . The temporal growth pattern of a city Surat is studied first to understand the compactness characteristic of sprawl and then sprawl characteristics Lucknow city are studied. It is observed that it is sprawling horizontally and city planners needs to manage the haphazard growth. The idea behind it is to understand the city sprawl characteristic for policy making and to identify the need of Supra Region Authority. Remotely Sensed Images were used for Land use land cover mapping, to study the change in different land covers. Satellite data acquisition is done from the USGS website and the imageries are formed by layer stacking the bands available. The projection system is UTM and zone 43N,44N with WGS 84 Datum. Different planning boundaries were studied from the documents available and Extended Master Plan Boundary was finalized looking into the growth scenario. As some of the inventory data obtained was not in spatial format, it had to be digitized and linked with the Land use. Then supervised classification was carried and six classes were extracted from imageries. To identify the urban growth drivers, the city is studied form various documents made available from local bodies and then primary factors were identified. Locations of important growth drivers are identified, digitized and then they were mapped as Factor maps. Normalization is also done for these maps. These factor maps and LULC maps are the inputs of the growth modelling software which will simulate the urban growth and identify the probable areas of growth in planning area.

\subsection{Inventory Data}

To study the growth pattern and regional setting of the city, location of neighbouring cities and villages were obtained from the urban development authority (UDA) of respective cities (table 2). The Census of India provided data for the years 1993, 2003 and 2013 to know the demography and socio economic details. To understand any city, master plan documents are the best sources. The administrative boundaries- city limits, Planning area boundary, Metropolitan area boundary and district boundary were extracted from the Municipal Corporation of Lucknow and Surat. There is always a question of which boundary is considered when it comes to planning a city. The premises play a major role so as to identify growth regions and to abide them into bye laws or others for the planned development.

The data related to working population, migration and the location of Central Business Districts in the Surat and Lucknow City were collected from the Lucknow Master Plan 2021 and used for the purpose. To suggest planning strategies and draw inferences from the policies existing when compared with the outputs of the research, various policies and governance documents were referred made available from various government departments.

The scaling of different types of maps have been standardized as shown in Table 1. Bhuvan satellite data and thematic GIS data resources available can be mapped according to the NRSC which gets updated time to time as per the ISRO/DOC policies. 
The Land Use/ Land Cover data can be mapped at scales 1:50,000 and 1:2,50,000 applicable for entire India but for different time periods. In this study, raster and factor maps are scaled at 1:2,50,000.

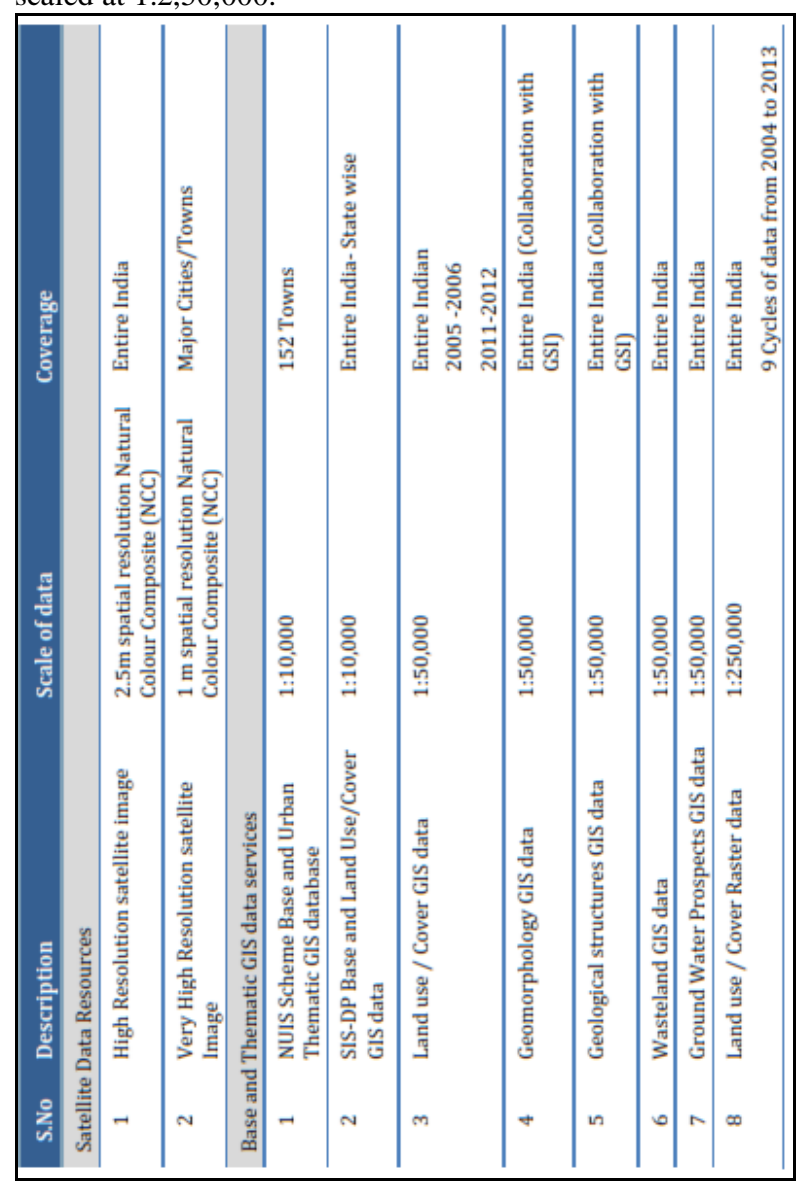

Table 1: Scale Of Mapping

\begin{tabular}{|l|l|l|l} 
& Surat & Lucknow & Source \\
\hline $\begin{array}{l}\text { Satellite } \\
\text { Data } \\
\text { (Landsat) }\end{array}$ & 1991,2005, & 1993,2003, & USGS \\
\hline $\begin{array}{l}\text { Existing } \\
\text { LULC }\end{array}$ & 2011,2014 & 2013 & \\
\hline $\begin{array}{l}\text { Demographic } \\
\text { Data }\end{array}$ & $1991-2016$ & $1991-2013$ & $\begin{array}{l}\text { Census of } \\
\text { India }\end{array}$ \\
\hline $\begin{array}{l}\text { Road and } \\
\text { Rail Network }\end{array}$ & 2016 & & $\begin{array}{l}\text { OSM, } \\
\text { DFCCIL, } \\
\text { TCPO }\end{array}$ \\
\hline $\begin{array}{l}\text { Water } \\
\text { Bodies, } \\
\text { Streams, } \\
\text { Drains and } \\
\text { Wetlands }\end{array}$ & 2016 & & Lucknow \\
\hline $\begin{array}{l}\text { Development } \\
\text { Plan }\end{array}$ & 2035 Map & & OSM \\
\hline
\end{tabular}

Table 2: Dataset and Source

\subsection{Satellite Data}

LANDSAT data was downloaded from USGS website as it is an Open Source for preparing the land use land cover maps for three decadal years. The spatial resolution of the data is 30 metres. High resolution imageries were not acquired for the study because for mapping sprawl and modelling the urban growth, the LANDSAT resolution with $30 \mathrm{~m}$ is good enough. If we want to classify the image for Level II, then high resolution imageries should be used. The dataset used is mentioned below. LANDSAT 7 and 8 data were used for LULC mapping. The dates on which the data was acquired and other details are given in Table 3

\begin{tabular}{|c|c|c|c|c|c|}
\hline 量 & 흘 & 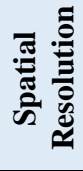 & O & 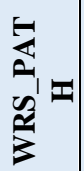 & 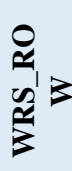 \\
\hline TM & $12-03-91$ & $30 \mathrm{~m}$ & $\begin{array}{r}\text { LT51480519 } \\
\text { 91071ISP00 }\end{array}$ & 148 & 045 \\
\hline ETM & $26-03-05$ & $30 \mathrm{~m}$ & $\begin{array}{r}\text { LE714804520 } \\
05085 \text { PFS00 }\end{array}$ & 148 & 045 \\
\hline TM & $30-01-11$ & $30 \mathrm{~m}$ & $\begin{array}{r}\text { LT51480452 } \\
011030 \mathrm{KHC00}\end{array}$ & 148 & 045 \\
\hline ETM & $4-04-14$ & $30 \mathrm{~m}$ & $\begin{array}{r}\text { LE71480452 } \\
014094 \text { PFS00 }\end{array}$ & 148 & 045 \\
\hline TM & $5-03-93$ & $30 \mathrm{~m}$ & $\begin{array}{r}\text { LT514404119 } \\
93064 \text { ISP01 } \\
\end{array}$ & 144 & 041 \\
\hline ETM & $10-04-03$ & $30 \mathrm{~m}$ & $\begin{array}{r}\text { LE714404120 } \\
\text { 03100ASN00 }\end{array}$ & 144 & 041 \\
\hline ETM & $13-04-13$ & $30 \mathrm{~m}$ & $\begin{array}{r}\text { LC81440412 } \\
013103 \text { LGN01 }\end{array}$ & 144 & 041 \\
\hline
\end{tabular}

Table 3: Satellite Dataset

The LANDSAT data was used to prepare Land Use Land Cover (LULC) Maps for 1993, 2003, 2013 for Lucknow Master Plan Area and 1991,2005,2011 and 2014 for SUDA area. USGS Level I Classification for LULC mapping has been used. Six classes named Built-up, Forest, Fallow/Open Land, Sparse Vegetation/Shrub land, Water bodies and Agricultural Land were classified. Urban growth pattern extraction and change detection was done on the LULC maps. Preparation of Binary maps of built-up and non-built-up was done. Factor maps for growth drivers of the planning area were made by Euclidean distance technique in ArcGIS software.

Urban Growth Drivers: The identified urban growth drivers are Central business district, major roads, minor roads, location of airport, protected areas and water bodies. Urban growth drivers with buffers $200,250,500,750$ and by default were made by the "Euclidean Distance" tool in Spatial Analyst in ArcMap. The Euclidean distance tools describe each cell's relationship to a source or a set of sources based on the straight-line distance. The source identifies the location of the objects of interest, such as wells, shopping malls, roads, and forest stands. If the source is a raster, it must contain only the values of the source cells, while other cells must be No Data. If the source is a feature, it will internally be transformed into a raster when you run the tool. Euclidean distance is calculated from the center of the source cell to the center of each of the surrounding cells. True Euclidean distance is calculated in each of the distance tools. 


\section{ANALYSIS}

\subsection{Urban Sprawl Pattern Analysis:}

Urban sprawl phenomena can be analyzed by the change in the areas of classes into one another. Figure 2 gives insights regarding the Urban Sprawl Scenario of Surat and economical establishments around which there will be possibility of growth. The compact scenario in this study is to distribute the projected growth of the city with its neighboring growth centers within the metropolitan region, to form a Regional Cluster. The Land Use Zoning concept is discussed for the compact scenario in the following Section. Figure 3 shows the nodes with population higher than 10000 to understand the current trend of development in the region of Surat. Population nodes and activity nodes are correlated with the development and population growth to identify future nodes for development with reference to the current scenario. 18 nodes were identified which can be developed as regional nodes to form a regional cluster.

Theses nodes are identified away from existing development These nodes are identified based on the location i.e. Major interchanges i.e. Railway Stations, Highway Interchanges, Existing Growth Trend and Most Importantly the interchanges on the proposed Outer Ring Road. It is proposed to develop these regional nodes as multimodal hubs and Transit Oriented Nodes / Transit Oriented Zones and further public transport facilities must be developed connecting these resulting in to Development Oriented Transit. It is already envisaged that the Metro Line will be developed along the outer ring road.

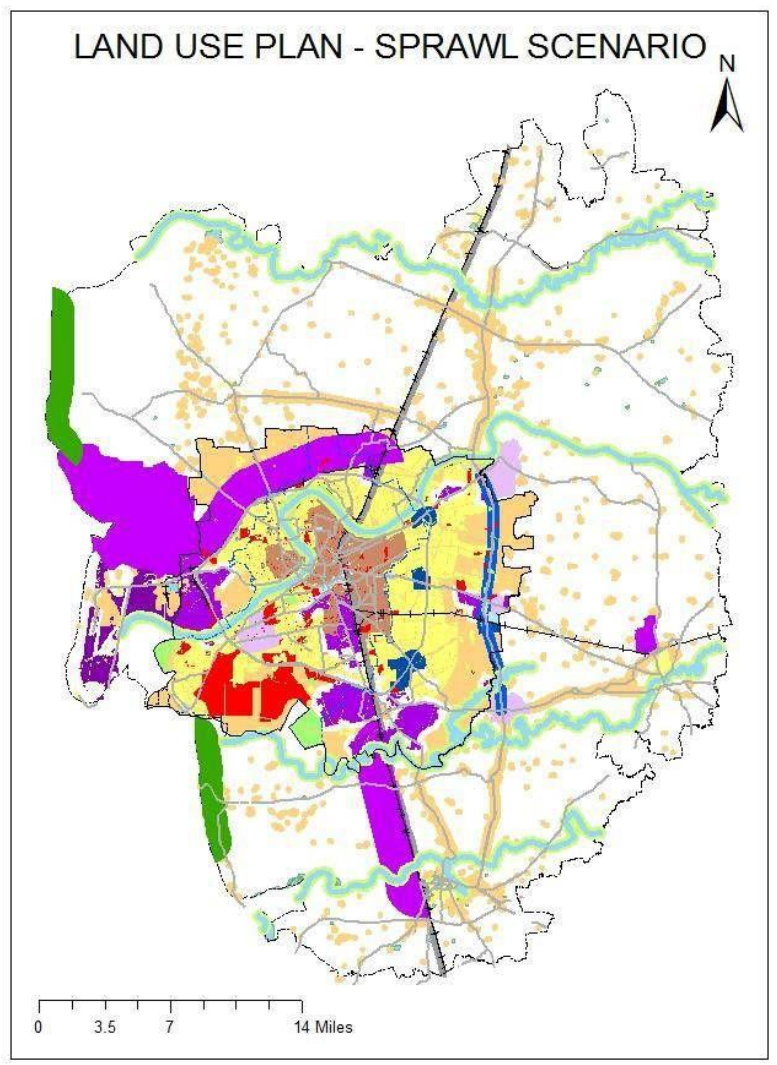

Figure 2: Urban Sprawl Scenario Surat

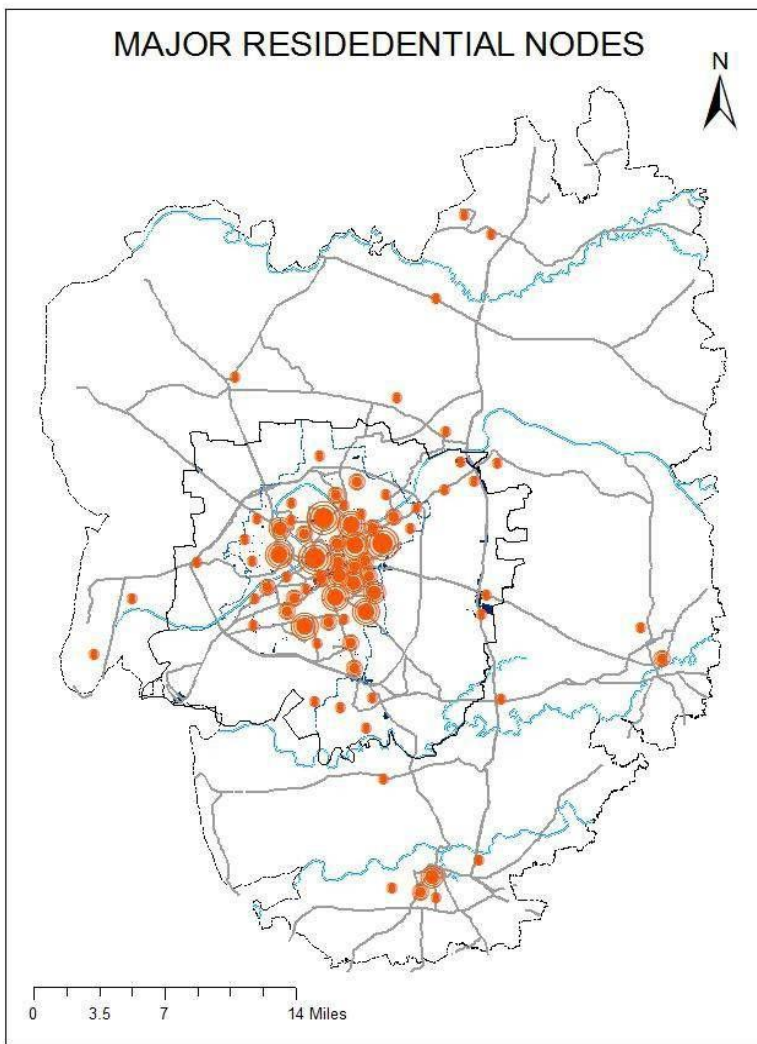

Figure 3: Nodes with Population> 1000 (Surat)

By development of these regional nodes, metro alignment can be developed on a regional scale essentially connecting these Nodes. From the property tax data obtained from Surat Municipal Corporation, the existing scenario of residential unit area and the existing structure of unit areas with governing land use of the area were identified to calculate future trends i.e. how much population can be accommodated in the TOZ i.e. regional nodes Table- 4 shows the current scenario of average residential unit area based on governing land use of the area.

\begin{tabular}{|l|c|c|c|}
\hline $\begin{array}{c}\text { Governing } \\
\text { Land } \\
\text { Use }\end{array}$ & $\begin{array}{c}\text { Total } \\
\text { Residential } \\
\text { Property } \\
\text { Area } \\
\text { (Sq.m.) }\end{array}$ & $\begin{array}{c}\text { Total } \\
\text { Residential } \\
\text { Properties } \\
\text { (Nos.) }\end{array}$ & $\begin{array}{c}\text { Average } \\
\text { Residential } \\
\text { Property } \\
\text { Size } \\
\text { (Sq.m.) }\end{array}$ \\
\hline Residential & 32354191.02 & 602694.00 & 53.7 \\
\hline Commercial & 645455.38 & 15696.00 & 41.1 \\
\hline Industrial & 4841341.64 & 132679.00 & 36.5 \\
\hline Planned & & & \\
Residential & 18794061.55 & 328413.00 & 57.2 \\
\hline
\end{tabular}

Table 4: Average Unit Area of Household with governing land Used 
Considering Table-4, maximum total population that can be accommodated in identified 18 Regional Nodes was calculated. Average $\mathrm{HH}$ unit size for residential node as 60 Sq. m, 45 sq.m. for Commercial Node and 40 Sq. for Industrial Node. Average household size is also considered as per the current scenario i.e. Average household size in 4.6 for residential and commercial is 4.6 and 4.3 industrial node.

It is evident this type of regional nodes will create high density compact neighbourhoods and the influence area can be developed as reduction in density with increasing distance from the node.

Figure 4 shows the regional nodes and their influence area i.e. 2 sq.km. Hence the further development should only take place in such influence areas with transit supportive land use.

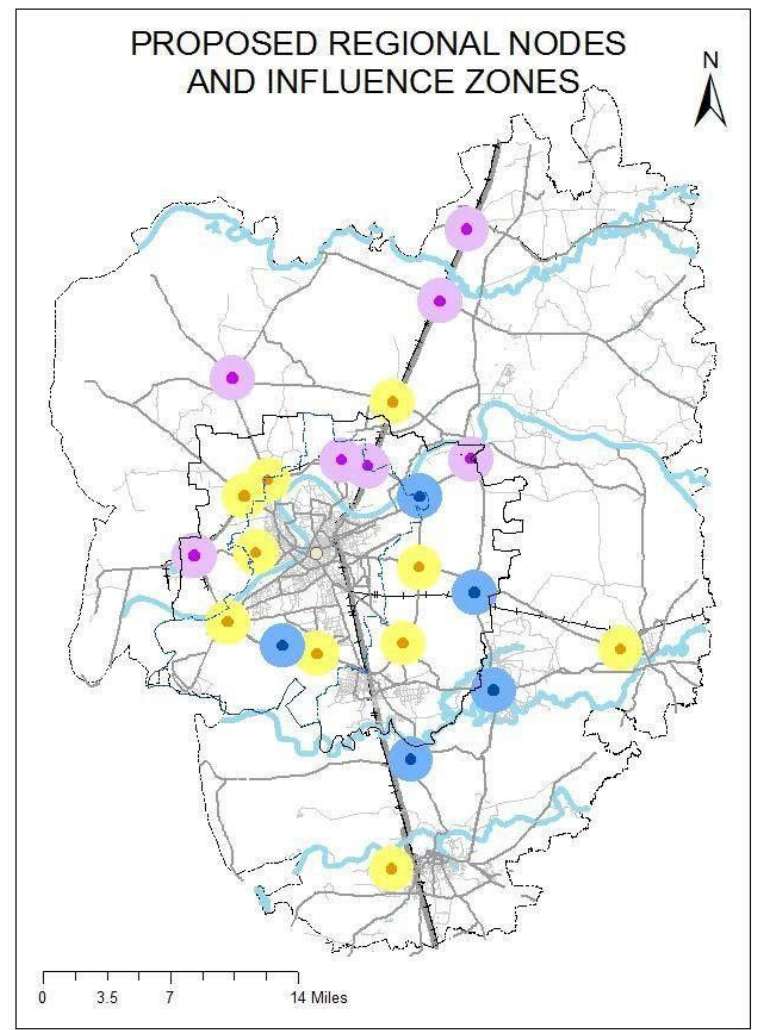

Figure 4: Proposed Regional Nodes with Governing Land Use

This type of development compels on having some Supra Regional Authority. As, Governance in India is three tier system. This three-tier system based on a hierarchy of authority and responsibilities may not be adequate for managing an agglomeration area or a metropolitan area. In India almost all the million plus cities and their agglomerations are multi district and multi municipal. In all of them the State and Central government agencies and departments are active. All of them also have significant entities of trade, commerce and service provision in the private sector. It is essential to recognize that a metropolitan area is an intergovernmental entity.

The issue persists in the region for development is the lack of Integration between different agencies, a global database and collective approach. While planning for development, Information exchange between agencies on development projects is mostly absent.

To understand the need of Supra authority, study on Lucknow city is carried out. As Lucknow is horizontally sprawled city, the aim is to find if the horizontal development of Lucknow city can be fit to Compact development

Here, analysis for LULC maps of Lucknow has been done as shown in Figure 5. As shown in Table 5, areas in sq. km. of each class for the three decadal years give us the idea of the change in the land use/land cover and activities along time periods in Lucknow Planning Area. There is a huge weightage of agriculture in all the three decadal years.
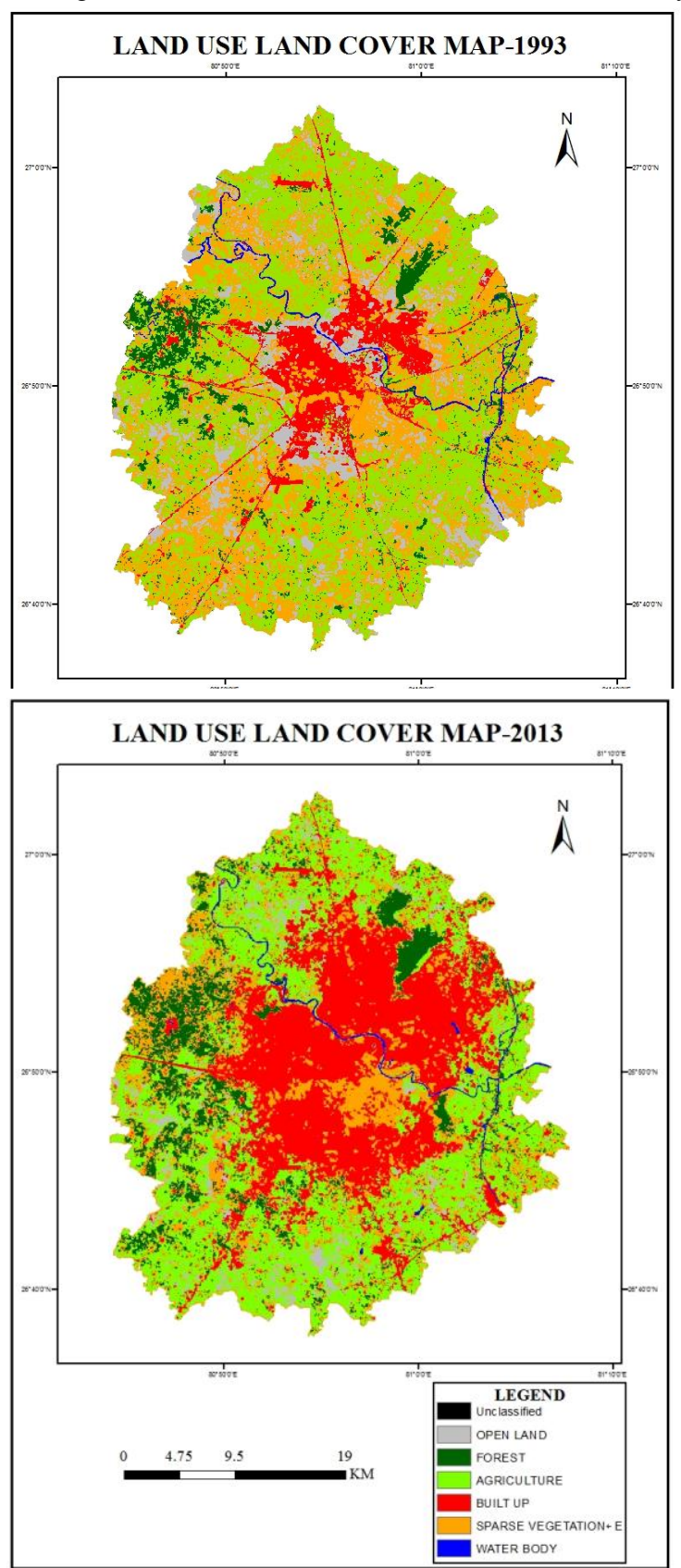

Figure 5: LULC Map of Lucknow

A drastic change can be observed from the maps of 1993 and 2003 in the sparse vegetation land cover from $41.5 \mathrm{sq}$. km. to 23.4 sq. $\mathrm{km}$. respectively. The built-up has prominently increased from 10.08 sq. km. in 1993 to 16.05 sq. km. and further into $34.42 \mathrm{sq}$. km. respectively. The total area of the planning area came out to be approximately $1167.46 \mathrm{sq} . \mathrm{km}$. 


\begin{tabular}{|c|c|c|c|c|}
\hline \multirow{2}{*}{$\begin{array}{l}\text { S. } \\
\text { No. }\end{array}$} & \multirow[b]{2}{*}{ CLASSES } & \multicolumn{3}{|c|}{ AREA (Sq. Km.) } \\
\hline & & 1993 & 2003 & 2013 \\
\hline 1 & $\begin{array}{l}\text { Fallow/Open } \\
\text { Land }\end{array}$ & 12679.7 & 24567.1 & 4626.72 \\
\hline 2 & Forest & 6693.39 & 8629.02 & 11717.4 \\
\hline 3 & $\begin{array}{l}\text { Agricultural } \\
\text { Land }\end{array}$ & 44609.8 & 43101.1 & 40079.8 \\
\hline 4 & Built-up & 10079.5 & 16052.8 & 34426.7 \\
\hline 5 & $\begin{array}{l}\text { Sparse } \\
\text { Vegetation }\end{array}$ & 41515.4 & 23420.6 & 24893.5 \\
\hline 6 & $\begin{array}{l}\text { Water } \\
\text { Bodies }\end{array}$ & 1168.38 & 966.06 & 1002.06 \\
\hline \multicolumn{2}{|c|}{ TOTAL } & 116746.17 & 116736.68 & 116746.18 \\
\hline
\end{tabular}

Table 5: Area Analysis of all Classes (Lucknow)

Table 6 shows the distribution of each class in the LULC maps of 1993, 2003 and 2013 based on area. The percentage rise between the two consecutive decadal years were also analyzed. The built up has changed drastically. In the 1993-2003 decadal year, $59.26 \%$ shows a great change in built up and in the 2003 2013 decadal year, $\mathbf{1 1 4 . 4 6} \%$ depicts well that the growth was maximum during this period. Sparse vegetation also changed dramatically $6.29 \%$ during the 2003-2013-time period. Forest reserve were taken into consideration and preservation efforts are clearly visible as $\mathbf{2 8 . 9 2 \%}$ during the 1993-2003 periodical change and $35.79 \%$ during 2003-13 decade. The water bodies have fallen drastically during $1993-2003$ by $17.32 \%$ and risen $3.73 \%$ slowly. Sparse vegetation has been reduced in 19932003 decadal period due to sudden urbanization and most of the land have been converted into built up or other usage. Agricultural land have been reducing since decades even though the food demand has been increasing due to population explosion.

\begin{tabular}{|c|c|c|c|c|c|c|}
\hline \multirow{2}{*}{ S. No. } & CLASSES & \multicolumn{3}{|c|}{$\%$ DISTRIBUTION } & \multicolumn{2}{c|}{$\%$ RISE } \\
\hline & & $\mathbf{1 9 9 3}$ & $\mathbf{2 0 0 3}$ & $\mathbf{2 0 1 3}$ & $\mathbf{1 9 9 3 - 2 0 0 3}$ & $\mathbf{2 0 0 3 - 2 0 1 3}$ \\
\hline $\mathbf{1}$ & Fallow/Open Land & 11 & 21 & 4 & $\mathbf{9 3 . 7 5}$ & -81.17 \\
\hline $\mathbf{2}$ & Forest & 6 & 7 & 10 & $\mathbf{2 8 . 9 2}$ & $\mathbf{3 5 . 7 9}$ \\
\hline $\mathbf{3}$ & Agricultural Land & 38 & 37 & 34 & -3.38 & -7.01 \\
\hline $\mathbf{4}$ & Built up & 9 & 14 & 30 & $\mathbf{5 9 . 2 6}$ & $\mathbf{1 1 4 . 4 6}$ \\
\hline $\mathbf{5}$ & Sparse Vegetation & 35 & 20 & 21 & -43.59 & 6.29 \\
\hline $\mathbf{6}$ & Water Bodies & 1 & 1 & 1 & -17.32 & $\mathbf{3 . 7 3}$ \\
\hline & Total & $\mathbf{1 0 0}$ & $\mathbf{1 0 0}$ & $\mathbf{1 0 0}$ & - & - \\
\hline
\end{tabular}

Table 6: Percentage distribution and rise in LU/LC for each Class(Lucknow)

Figure 6 showing built-up and non-built up areas has been prepared in order to extract the sprawl pattern and identify the areas which underwent change over decadal time periods. The built up was 10079.5 hectares in 1993, 16052.8 ha.in 2003 and 34426.7 ha.in 2013 respectively. The LULC maps of the three years were one by one recoded individually where all other classes except built-up were set to zero and built-up was set as "1". In this way, only built-up and non-built-up classes were left which turned out to be the binary maps as " 0 " and " 1 ". This was done by the tool "Recode" in the "Thematic" tab in ERDAS Imagine 2014 software. This is so easy to change the number of classes and even to merge the classes. This can also be done in ArcGIS software.
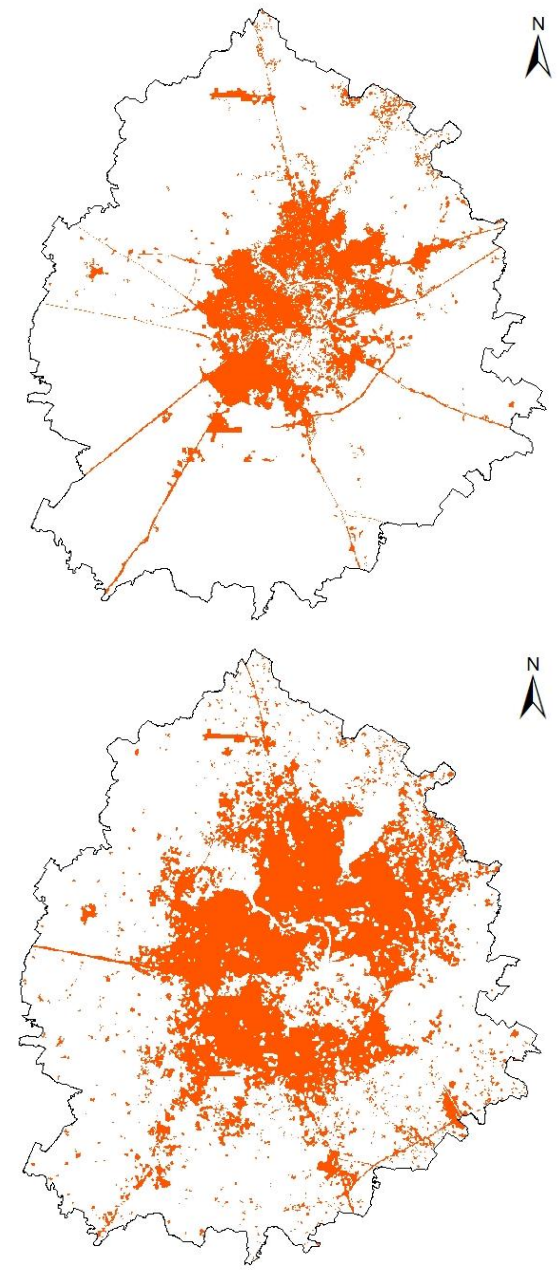

Figure 6: Binary Maps of Built-up (2003,2013)

Change Detection: The transitions from one class to another were obtained from the Matrix Union tool in Erdas Imagine 2014. Both the LULC's were the inputs and the output were shown in the attribute table as each class being changed into class number 1,2,3, etc. and then it was copied and analyzed in the Microsoft Excel to find out the changes. The major change occurred due to transition from sparse vegetation, agricultural land, fallow/open land into Built up left as fallow land. Also that it will be converted into open land and made usable for built-up. In Error! Reference source not found. by 4.22 sq. km., 6.50 sq. km. and 9.88 sq. km. respectively. The transition of sparse vegetation into agricultural land, quantified as 4.28 sq.km. The transition of agricultural land into sparse vegetation was 7.10 sq.km, fairly justified as the agricultural land is seasonally used and $\mathbf{5 . 3}$, all the transitions from other classes converted into built-up are shown. The maximum conversion of land use into built up was of sparse vegetation of the value 3.08 sq. km (Figure 7.0) i.e. 67\%. 


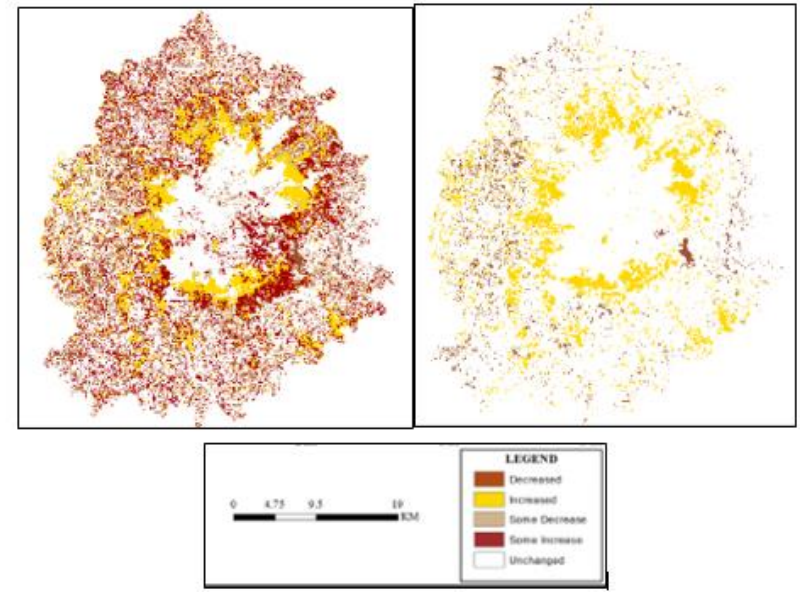

Figure 7: Change Detection for Decade 20032013(Lucknow)

\section{GROWTH MODELLING}

The urban growth has to be monitored and studied well yearly in order to better implement the master plans or any other plans. The modeling techniques can be helpful tools for the purpose. As seen in the literature review, cellular automata models can be helpful to understand the temporal changes of an area, so we have decided to use this technique for growth modeling of Lucknow Planning Area

The urban growth of Lucknow city has been tremendously dynamic and fast in nature. The built-up of LULC maps were extracted out from them and overlaid on one another to see how the city has actually sprawled in the Planning Area. Figure 8 depicts the overlaid built up maps where the growth can be seen particularly in the north-eastern and western directions from the main core of the city. The reserved areas have been taken care of and the restriction of built up in this area and the can't area have been implemented well. A zoomed in image was also captured to understand the infill growth in the core city. A significant amount of growth can be seen outside the cantonment area in the year 2003 on the eastern side.

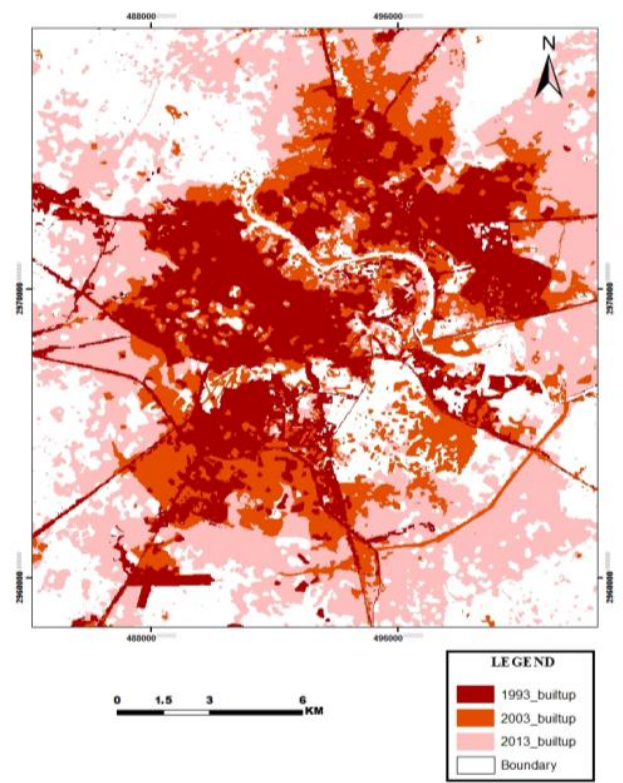

Figure 8: Built up 1993,2003,2013
The protected areas in Lucknow Planning Area has been preserved well since 1993 in fact it had been taken care of well than before. The built-up encroaching these areas is a normal phenomenon. The adjacent sparse vegetation and agriculture land has been converted into built-up but the protected areas have been preserved well till 2013 The airport is generally a restricted area around which the built-up is not allowed. But in the past few decades, the places around the airport were used. The built-up in the northern side of airport clearly shows that it had grown so drastically during 1993-2013. The leapfrogging development along the road adjacent to airport is the main reason of the built-up near airport. There is a need to channelize the growth without compromising the rules and regulations or bye laws set by govt. and local bodies.

\section{RESULTS AND DISCUSSION}

Study investigates urban dynamics over Surat and Lucknow city, by focusing on six categories of LULC: Fallow Land, Forest, Agricultural Land, Built-up, Sparse Vegetation's and water bodies. Remote sensing and earth observation methods coupled with GIS techniques were successfully used to identify the spatial-temporal process of urban growth using Landsat data for three decadal time periods The LULC mapping were accurate to the levels of $88 \%, 90 \%$ and $93 \%$ for the years 2013, 2003 and 1993 respectively. The transitions between classes of LULC were analysed and observed to understand the changes taking place in the area. CA Markov process in IDRISI software was used to model the growth and predict the future land use land covers.

The projected LULC map for 2013 was checked with the existing LULC map for 2013 and then it was proceeded to project the LULC map for 2023. This was then compared with the planning provisions given for the year 2021 in Master Plan. The land use and land covers were discussed to cross check the probable areas for future growth as per master plan 2021 and the LULC mapping. Also the growth near restricted areas were discussed. The areas near airport are being drastically covered with built-up which needs to be controlled further. The industrial setups inside the planning area should be allotted in accordance with the LIDA rules as well.

It is evident that the city structure is expanding its urban fabric on the adjoining areas engulfing the nearby villages and hence occupying the agricultural lands in the subsequent process of expansion. The villages are being covered very soon and this needs to be looked into for socio-economic changes that occur. Change detection Technique has evidently shown that the nature of growth in Surat is compact inherently. Demographics shows that the population in SUDA region increased at 1.5 times rate, but the residential land use remained $50 \%$ of the proposed land use.

Urban Growth in the region is taking place along the major transit corridors and hubs, resulting in the Ribbon sprawl development.

Proposed Development plan for SUDA has ambiguities which over estimates the land requirements, which is against sustainability as the land is an asset and the more agriculture land is converted in urban land, the land will lose the fertility which will affect the economic scenario of the region.

Surat Metropolitan Area is delineated in the study which includes Surat Urban Development Authority, Navsari Urban Development Authority, Bardoli Urban Development Authority, 
Khajod Development Authority and Villages from other these jurisdictions as well. The delineation is done based on factors i.e. population, density, growth of built up and connectivity of major growth nodes.

Projection for population is carried out for year-2035, which amounts to be around 14 million in the year by incremental increase method. To accommodate this population, the spatial and temporal analysis was carried out and it was concluded that there is no need for expansion of any urban body, as the available land is adequate for urban development.

Also, constraint maps were prepared to identify the areas where development should be controlled and restricted.

Recreational area and open space are considerably low than required according to URDPFI guidelines, hence it should be emphasized to develop green and recreational spaces for the region.

Two scenarios are proposed for accommodating the growth for year-2035:

Sprawl Scenario, in which the development will take place as current nature

Compact Scenario, in which 18 regional nodes are proposed, which can be developed as TOZ and they will encourage a compact land use in the region, which will be sustainable.

Various land use such as Industrial, Commercial, Recreational are identified to develop, which will encourage the inclusive sustainable development and increase the quality of life and overall attraction of the region as well.

\section{CONCLUSIONS}

The major objectives of the study are to understand the nature of development in Surat and surrounding area, delineate a metropolitan area and propose land use zoning and a unique authority (Supra) to implement land use plans and development control regulations. It aids in rationalization of planning in a regional context for Surat and its surrounding areas. Compact growth of Surat city is understood in correspondence with Horizontal sprawl of Lucknow city. There has been clear evidence of haphazard development of city as per the temporal and spatial analysis of land use land cover maps. The results of those maps can be used for general discussion on how the LULC Maps can be utilized to predict the future growth trends and how growth drivers affect the built-up. Also the growth modelling can be incorporated in the master plans efficiently. to curb the haphazard development, to implement the conceptualized metropolitan area and land use, a Supra Regional Authority (SURAt) is required with policy frame work. Which will be benefitted in governance and over all spatial development of the region. This types of policy intervention along with geospatial technology will implement the Land Use Zoning and spatial development control.

\section{REFRENCES}

Atiqur Rahman, S. P. (2011). Monitoring Urban Sprawl Using Remote Sensing and GIS Techniques of a Fast Growing Urban Centre, India. IEEE journal of selected topics in applied earth observations and remote sensing, 56-65.

Cohen, B. (2004). Urban growth in developing countries: a review of cureent trends and a caution regarding existing forecasts. World Dev. 32, 23-51.
Bakiratas, T. (2018). The relationship between energy consumption, urbanization, and economic growth in new emerging market countries. Energy 147, 110121.

Barnes, K. B., Morgan, J. M. Roberge, M. C., Lowe, S. (2001). Sprawl Development:Its Patterns, Consequences, and Measurement. Retrieved from Towson University: http://chesapeake.towson.edu/landscape/urbansprawl/ download/Sprawl_white_paper.pdf

Liu, Y. F. (2014). Key Issues of land Use in China and implications for Policy Making. Land Use Policy 40, 6-12.

Liu., Y. (2018). Introduction to land use and rural sustainability in China. Land Use Policy, 1-4.

Netzband, M., Stefanov, W. L., Redman, C. (2007). Applied Remote Sensing for Urban Planning, Governance and Sustainability. Springer.

Pollock, P. (2008). Urban Growth Management Strategies. Sustainable Community Development Code.

Raghavswamy, V., Pathan, S. K., Ram Mohan, P., Bhanderi, R. J., Padma Priya (1996). IRS-1C applications for urban planning and development. Current Science, $70,582-588$

Soomro, A. G., Babar, M. M., Arshad, M., Memon, A., Naeem, B., \& Ashraf, A. (2020). Spatiotemporal variability in spate irrigation systems in Khirthar National Range, Sindh, Pakistan (case study). Acta Geophysica, 68(1), 219-228. https://doi.org/10.1007/s11600-019-00392-1

Tsutsumida, N. S. (2015). Addressing urban expansion using feature-oriented spatial data in aperipheral area of Ulaanbaatar, Mongolia. Habitat International, 47, 196-204.

Wang, J. Y. (2018). Land-use Changes and Land Policy evaluation in China's urbanization processes. Land Use Policy 75, 375-387. 